\title{
Plasmid-mediated quinolone resistance in Escherichia coli strains isolated from animals in Turkey"
}

\author{
H. Kaan MÜŞTAK ${ }^{1}$, Tuba İÇA ${ }^{2}$, Alper ÇİFTCí ${ }^{3}$ K. Serdar DİKER ${ }^{1}$ \\ ${ }^{1}$ Department of Microbiology Faculty of Veterinary Medicine Ankara University, Ankara; ${ }^{2}$ Department of Biology Faculty of Arts \\ and Sciences Dumlupınar University, Kütahya; ${ }^{3}$ Department of Microbiology Faculty of Veterinary Medicine Ondokuz Mayıs \\ University, Samsun, Turkey.
}

\begin{abstract}
Summary: Chromosomal mutations and resistance genes transferred by plasmids are the main factors of quinolone resistance particularly in Escherichia coli strains isolated from both animals and humans. In this study a total of 259 E. coli strains were examined for the resistance to nalidixic acid and ciprofloxacin by agar dilution method and for the presence of $q n r \mathrm{~A}, q n r \mathrm{~B}$ and $q n r \mathrm{~S}$ genes that are known as plasmid-mediated quinolone resistance determinants by PCR. According to antimicrobial susceptibility tests $47(50.0 \%)$ of 94 chicken, $3(4.5 \%)$ of 66 sheep, $5(9.6 \%)$ of 52 cattle and $3(6.4 \%)$ of 47 dog E. coli strains were found to be resistant to ciprofloxacin. Among all plasmid-mediated quinolone resistance determinants that were investigated in this study, only $q n r \mathrm{~A}$ gene was found in $5(5.3 \%)$ of $94 \mathrm{E}$. coli chicken isolates. This is the sole report from Turkey that evaluated the plasmidmediated quinolone resistance in animal isolates of $E$. coli strains.
\end{abstract}

Key words: Animal, Escherichia coli, plasmid-mediated, quinolone-resistance

\section{Türkiye’de hayvanlardan izole edilen Escherichia coli suşlarında plasmid iliş̧ili kinolon direnci}

Özet: Hayvanlarda ve insanlarda çok çeşitli infeksiyonlara neden olan Escherichia coli'lerde kinolon direnç gelişimine neden olan başlıca faktörler kromozomal mutasyonlar ve plazmidler ile aktarılan direnç genleridir. Bu çalışmada toplam 259 E. coli suşu, nalidiksik asit ve siprofloksasin direnci, agar dilusyon yöntemi kullanılarak ve plazmid ilişkili kinolon direnç belirleyicilerinden olan $q n r \mathrm{~A}, q n r \mathrm{~B}$ ve $q n r \mathrm{~S}$ genlerinin varlığı PCR yöntemi kullanılarak araştırıldı. Antibiyotik duyarlılık test sonuçlarına göre 94 tavuk $E$. coli suşundan 47 (\%50)'si, 66 koyun E. coli suşundan 3 (\%4.5)'ü, 52 sığır E. coli suşundan 5 (\%9.6)'i, 47 köpek E. coli suşundan 3 (\%6.4)'ü siprofloksasin'e dirençli bulundu. Bu çalışmada araştırılan bütün plazmid ilişkili kinolon direnç belirleyicileri içerisinden, izole edilen 94 E. coli tavuk suşu arasında qnrA geni, sadece 5 (\%5.3) tavuk izolatında bulundu. Bu çalışma, Türkiye'de E. coli hayvan izolatlarında plazmid ilişkili kinolon direncinin değerlendirildiği tek rapordur.

Anahtar sözcükler: Escherichia coli, hayvan, kinolon direnci, plazmid ilişkili

\section{Introduction}

Escherichia coli is one of the most common microorganism, which affects both animals and humans worldwide by a wide spectrum of diseases ranging from opportunistic wound infection to severe systemic infections. The zoonotic potential, complicated antigenic structure and toxins give importance to $E$. coli in prophylaxis and treatment regimes (5).

Quinolones are broad-spectrum antibiotics widely used against Gram negative bacterial infections in both human and veterinary medicine nevertheless intensive and misuse of quinolones led to bacterial resistance. Chromosomal mutations in the quinolone resistancedetermining regions of DNA gyrase and topoisomerase IV and genes transferred by plasmids to susceptible bacterial strains are the main factors in acquiring rapid resistance to quinolones (22).
In 1998, plasmid-mediated quinolone resistance (PMQR) was first reported in a pMG252 plasmid of Klebsiella pneumoniae isolated from urine of a patient at the University of Alabama at Birmingham Medical Center (12). After this first record, qnr gene which encodes a 218 amino-acid protein (Qnr) of pentapeptide repeat family and produces low-level quinolone resistance, was cloned and sequenced from pMG252 plasmid (19). It was also reported that the Qnr protein protects DNA gyrase from ciprofloxacin (1) and increases resistance to fluoroquinolones and nalidixic acid $(12,15,16)$.

Alteration of drug target (DNA gyrase, topoisomerase IV), decreasing membrane permeability by changing porin protein structures, eliminating the effect of drug by using active efflux-pumps and plasmidmediated bacterial resistance are the known mechanisms

\footnotetext{
* Part of this study was funded by Ankara University Office of Scientific Research Projects (Project No: 200308056).
} 
involved in quinolone resistance $(15,16)$. Plasmidmediated bacterial resistance is determined by $q n r \mathrm{~A}$, formerly named $q n r(q n r \mathrm{~B}, q n r \mathrm{~S}, q n r \mathrm{C}, q n r \mathrm{D}$ are variants of $q n r$ gene, and encodes QnrB, QnrS, QnrC and QnrD proteins respectively), aac(6')- $\mathrm{Ib}-\mathrm{cr}$ (encodes an aminoglycoside acetyltransferase for enzymatic inactivation of quinolones) and qepA (encodes a new quinolone efflux pump protein, QepA) genes located on plasmids $(15,16)$.

There are several reports in other countries of the world that have investigated PMQR in veterinary clinical isolates of $E$. coli $(3,7,10,23)$. Although, quinolones are widely used in veterinary medicine in Turkey, there is no report of PMQR in E. coli strains of animal origin. This study aimed to investigate the prevalence of resistance to nalidixic acid and ciprofloxacin and the presence of $q n r \mathrm{~A}, q n r \mathrm{~B}$ and $q n r \mathrm{~S}$ genes as which are the PMQR determinants in $E$. coli strains isolated from animals of different origins.

\section{Materials and Methods}

Samples and bacteriological culture: Rectal swab, cloacal swab and stool samples collected from animals raised in commercial farms of Ankara province were investigated in Ankara University, Faculty of Veterinary Medicine, Department of Microbiology. Samples were inoculated onto MacConkey Agar (Oxoid, CM0007B), Eosin Methylene Blue Agar (Oxoid, CM0069B) and 5-7\% sheep Blood Agar (Oxoid, CM0055B) for bacteriological culture. After incubation at $37^{\circ} \mathrm{C}$ for $24-36 \mathrm{~h}$, suspected colonies were Gram stained and evaluated according to Bergey's Manual of Determinative Bacteriology (6). A total of 259 E. coli strains; 94 from broiler chickens, 66 from sheep, 52 from cattle and 47 from dogs were stored in Brain Heart Infusion Broth (Oxoid, CM1135B) with $15 \%$ glycerol at $-20^{\circ} \mathrm{C}$ for further investigation.

Antimicrobial susceptibility test: A modified agar dilution technique was used to determine minimal inhibitory concentration (MIC) values of nalidixic acid and ciprofloxacin according to the guidelines of Clinical and Laboratory Standards Institute (CLSI) (2). Briefly, from $512 \mu \mathrm{g} / \mathrm{ml}$ to $0.125 \mu \mathrm{g} / \mathrm{ml}$ serial two-fold dilutions of nalidixic acid and ciprofloxacin was prepared in Mueller-Hinton Agar (Oxoid, CM0337B). Bacterial suspensions were adjusted to McFarland 0.5 turbidity standard with sterile physiological saline and $2 \mu \mathrm{l}$ of this suspension was inoculated onto Mueller-Hinton Agar plates. After aerobic incubation at $37^{\circ} \mathrm{C}$ for $16-20 \mathrm{~h}$, agar plates were evaluated for MIC values. MICs of ciprofloxacin $\geq 4 \mu \mathrm{g} / \mathrm{ml}$ and nalidixic acid $\geq 32 \mu \mathrm{g} / \mathrm{ml}$ for resistance, MICs of ciprofloxacin $\leq 1 \mu \mathrm{g} / \mathrm{ml}$ and nalidixic acid $\leq 8 \mu \mathrm{g} / \mathrm{ml}$ were accepted as susceptible breakpoints as defined by CLSI (2). E. coli ATCC 25922 was used as quality control in all tests.

Detection of qnr genes: In order to determine PMQR, all E. coli isolates were subjected to polymerase chain reaction (PCR). DNA was extracted by boiling method (17) and E. coli J53Azir containing the plasmid pMG254 was used as qnrA positive quality control strain. Primers used for amplification of $q n r \mathrm{~A}, q n r \mathrm{~B}$ and $q n r \mathrm{~S}$ genes and sizes of amplified products are shown in Table 1. Thermal cycling conditions for $q n r \mathrm{~A}$-specific PCR were as follows: 30 cycles of denaturation at $94^{\circ} \mathrm{C}$ for $1 \mathrm{~min}$, annealing at $57^{\circ} \mathrm{C}$ for $30 \mathrm{sec}$ and extension at $72^{\circ} \mathrm{C}$ for $1 \mathrm{~min}$ (8). Same cycling conditions were applied for $q n r \mathrm{~B}$ and $q n r \mathrm{~S}$ except with a lower annealing temperature of $53^{\circ} \mathrm{C}$. PCR products were resolved by $1.5 \%$ agarose gel electrophoresis and visualized with ethidium bromide under UV transilluminator.

\section{Results}

A total of 259 E. coli strains; 94 from broiler chickens, 66 from sheep, 52 from cattle and 47 from dogs were isolated from collected samples. According to antimicrobial susceptibility tests, the number and percentages of ciprofloxacin and nalidixic acid resistant $E$. coli isolates and their distribution among animal origins are presented in Table 2.

Among all 259 E. coli isolates, $q n r \mathrm{~B}$ and $q n r \mathrm{~S}$ genes were not observed, whereas qnrA gene was found in $5(5.3 \%)$ of the 94 chicken isolates. MIC values and susceptibility to nalidixic acid and ciprofloxacin according to CLSI breakpoints of these 5 isolates are shown in Table 3. Among all 5 qnrA positive isolates, one isolate (Isolate 4) exhibited no resistance to either of the quinolones but two isolates (Isolate 1 and 2) were found to be resistant to both quinolones.

Table 1. Primers used for amplification of $q n r$ genes and PCR product.

Tablo 1. qnr genlerini çoğaltmak için kullanılan primerler ve PCR ürün büyüklükleri.

\begin{tabular}{cllll}
\hline Gene & Primer & Sequence (5'-3') & Size & Reference \\
\hline$q n r \mathrm{~A}$ & QP1 & GATAAAGTTTTCAGCAAGAGG & 593 bp & Jacoby et al. (8) \\
& QP2 & ATCCAGATCGGCAAAGGTTA & & \\
$q n r \mathrm{~B}$ & QnrB-A & GATCGTGAAAGCCAGAAAGG & $469 \mathrm{bp}$ & Gay et al. (4) \\
& QnrB-B & ACGATGCCTGGTAGTTGTCC & & \\
\multirow{2}{*}{$q n r \mathrm{~S}$} & QnrS-A & ACGACATTCGTCAACTGCAA & $417 \mathrm{bp}$ & Gay et al. (4) \\
& QnrS-B & TAAATTGGCACCCTGTAGGC & & \\
\hline
\end{tabular}


Table 2. Distribution of ciprofloxacin and nalidixic acid resistant strains among animal origins according to susceptibility test results. n: number of strains; CIP: ciprofloxacin; NAL: nalidixic acid.

Tablo 2. Antibiyotik duyarlılık test sonuçlarına göre siprofloksasin ve nalidiksik asit dirençli suşların hayvan kökenleri arasındaki dağılımı. n: suş sayısı; CIP: siprofloksasin; NAL: nalidiksik asit.

\begin{tabular}{lccccc}
\hline Quinolone & $\begin{array}{c}\text { Chicken } \\
(\mathrm{n}: 94)\end{array}$ & $\begin{array}{c}\text { Sheep } \\
(\mathrm{n}: 66)\end{array}$ & $\begin{array}{c}\text { Cattle } \\
(\mathrm{n}: 52)\end{array}$ & $\begin{array}{c}\text { Dog } \\
(\mathrm{n}: 47)\end{array}$ & $\begin{array}{c}\text { Total } \\
(\mathrm{n}: 259)\end{array}$ \\
\hline \multirow{2}{*}{ CIP } & 47 & 3 & 5 & 3 & 58 \\
& $(50.0 \%)$ & $(4.5 \%)$ & $(9.6 \%)$ & $(6.4 \%)$ & $(22.4 \%)$ \\
\multirow{2}{*}{ NAL } & 55 & 12 & 15 & 5 & 87 \\
& $(58.5 \%)$ & $(18.2 \%)$ & $(28.8 \%)$ & $(10.6 \%)$ & $(33.6 \%)$ \\
\hline
\end{tabular}

Table 3. MIC values and quinolone susceptibility of 5 qnrA positive chicken isolates according to CLSI breakpoints. R: resistant; I: intermediate; S: susceptible; CIP: ciprofloxacin; NAL: nalidixic acid.

Tablo 3. CLSI'nın belirlediği değerlere göre $5 q n r \mathrm{~A}$ pozitif tavuk izolatının MiK değerleri ve kinolon duyarlılıkları. R: dirençli; I: orta; S: duyarl1; CIP: siprofloksasin; NAL: nalidiksik asit.

\begin{tabular}{lccccc}
\hline \multirow{2}{*}{ Quinolone } & \multicolumn{5}{c}{ MICs $(\mu \mathrm{g} / \mathrm{ml})$} \\
& Isolate 1 & Isolate 2 & Isolate 3 & Isolate 4 & Isolate 5 \\
\hline CIP & $4(\mathrm{R})$ & $16(\mathrm{R})$ & $0.5(\mathrm{~S})$ & $0.5(\mathrm{~S})$ & $0.5(\mathrm{~S})$ \\
NAL & $64(\mathrm{R})$ & $512(\mathrm{R})$ & $32(\mathrm{R})$ & $8(\mathrm{~S})$ & $16(\mathrm{I})$ \\
\hline
\end{tabular}

\section{Discussion and Conclusion}

This study aimed to investigate the prevalence of nalidixic acid and ciprofloxacin resistance and the presence of $q n r \mathrm{~A}, q n r \mathrm{~B}$ and $q n r \mathrm{~S}$ genes in $259 \mathrm{E}$. coli strains isolated from animals of different origin.

In the present study, among $259 \mathrm{E}$. coli isolates, 58 $(22.4 \%)$ isolates and $87(33.6 \%)$ isolates were found resistant to ciprofloxacin and nalidixic acid, respectively, but only $5(5.3 \%)$ chicken isolates were found $q n r \mathrm{~A}$ positive by PCR. It is already known that $q n r$ genes increases resistance to fluoroquinolones and nalidixic acid $(12,15,16)$. This result and the high rate of $q n r \mathrm{~A}$, $q n r \mathrm{~B}$ and $q n r \mathrm{~S}$ negative but nalidixic acid and ciprofloxacin resistant $E$. coli strains lead us to consider other known ways of antimicrobial resistance mechanisms, such as chromosomal mutations in genes encoding DNA gyrase and topoisomerase IV.

Previous studies from Asia, United States and Europe exhibited the prevalence of $q n r$ gene in humans as $0.3-11 \%$ of the investigated strains which varies in different regions of the world, and revealed that $q n r$ gene in conjugative plasmids confers resistance to quinolones $(9,11,20,21)$. In Turkey, there is no data about PMQR in E. coli strains isolated from animals, despite few studies in humans. In 2008, Öktem et al. (14) found 5 $(6.3 \%)$ qnrA positive strains (1 qnrA positive $E$. coli and 4 qnrA positive $K$. pneumoniae) among extended- spectrum $\beta$-lactamase-positive $34 \mathrm{E}$. coli and $44 \mathrm{~K}$. pneumoniae strains isolated from the blood cultures of clinical patients. Whereas Nazik et al. (13) investigated $q n r \mathrm{~A}, q n r \mathrm{~B}, q n r \mathrm{~S}$ and $a a c\left(6^{\prime}\right)-l b-c r$ genes in 694 E. coli strains isolated from humans, and found only $3(0.4 \%)$ $q n r \mathrm{~A}$ positive E. coli strains. In the current study, PMQR determinant of qnrA gene was found in $5(1.9 \%)$ out of 259 E. coli isolates of different animals. It can be said that the PMQR gene prevalence rates of this study performed with animal isolates and the others performed with human isolates are compatible with the general prevalence rates taken from other regions of the world ( 9 , $11,20,21)$.

There are several reports from other countries of the world, which have investigated PMQR in veterinary clinical E. coli isolates. Yue et al. (23) investigated $\mathrm{PMQR}$ genes of $q n r \mathrm{~A}, q n r \mathrm{~B}, q n r \mathrm{~S}, a a c\left(6^{\prime}\right)-I b-c r$ in 232 poultry and swine clinical isolates of E. coli and found 14 (6\%) $q n r$ positive isolates of which 3 were pig, 2 were duck, and 8 goose isolates but none were qnrA positive. Also in 2009, Kuo et al. (10) investigated 660 E. coli strains isolated from pigs and chickens for the prevalence of $q n r(q n r \mathrm{~A}, q n r \mathrm{~B}$ and $q n r \mathrm{~S})$ and $q e p \mathrm{~A}$ genes. Kuo et al. (10) detected only $12(3.33 \%)$ and $6(2 \%) q n r \mathrm{~S}$ gene positive E. coli 360 pig and 300 chicken isolates, respectively. Fortini et al. (3), detected $12 q n r \mathrm{~S} 1,3$ qnr 19,1 qnrB10 PMQR determinants, but none of the isolates were qnrA positive in $162 \mathrm{E}$. coli strains isolated from healthy chickens and pigs. Huang et al. (7), evaluated 532 E. coli chicken isolates for PMQR determinants of $q n r$ gene and found $4(0.75 \%) q n r \mathrm{~A}$ positive strains. All these reports indicated the importance of $\mathrm{PMQR}$, despite the negative or low prevalence of $q n r \mathrm{~A}$ gene. In comparison with the $q n r \mathrm{~A}$ gene prevalence in human isolates, animal isolates shows low prevalence rates except the current study, which was found $5(5.3 \%)$ in $94 \mathrm{E}$. coli chicken isolates.

In Turkey, there is no report on the determination of quinolone resistance in E. coli strains in veterinary medicine. There is only one study, where Savasan et al. (18) investigated chicken Campylobacter isolates for quinolone resistance by agar dilution method. This is the first and only report from Turkey that investigated the PMQR determinant of $q n r$ gene in E. coli strains isolated from different animals. This study revealed that the PMQR, which was previously reported only from human E. coli isolates, could also be detected in animal isolates.

\section{References}

1. Bateman A, Murzin AG, Teichmann SA (1998): Structure and distribution of pentapeptide repeats in bacteria. Protein Sci, 7, 1477-1480.

2. Clinical and Laboratory Standards Institute (2009): Methods for Dilution Antimicrobial Susceptibility Tests for Bacteria That Grow Aerobically-Eight Edition: Approved Standard M07-A8. CLSI, Wayne, PA, USA. 
3. Fortini D, Fashae K, Garcia-Fernandez A, Villa L, Carattoli A (2011): Plasmid-mediated quinolone resistance and $\beta$-lactamases in Escherichia coli from healthy animals from Nigeria. J Antimicrob Chemother, 66, 1269-1272.

4. Gay K, Robicsek A, Strahilevitz J, Park CH, Jacoby GA, Barrett TJ, Medalla F, Chiller TM, Hooper DC (2006): Plasmid-mediated quinolone resistance in NonTyphi serotypes of Salmonella enterica. Clin Infect Dis $\mathbf{4 3}$, 297-304.

5. Gyles CL, Fairbrother JM (2010): Escherichia coli. 267308. In: Gyles CL, Prescott JF, Songer JG, Thoen CO (Eds), Pathogenesis of Bacterial Infections in Animals. Blackwell Publishing, Singapore.

6. Holt JG, Krieg NR, Sneath PHA, Staley JT, Williams ST (2000): Bergey's Manual of Determinative Bacteriology (9th ed). Williams \&Wilkins, USA.

7. Huang SY, Dai L, Xia LN, Du XD, Qi YH, Liu HB, Wu CM, Shen JZ (2009): Increased Prevalence of PlasmidMediated Quinolone Resistance Determinants in Chicken Escherichia coli Isolates from 2001 to 2007. Foodborne Pathog Dis, 6 (10), 1203-1209.

8. Jacoby GA, Chow N, Waites KB (2003): Prevalence of Plasmid-Mediated Quinolone Resistance. Antimicrob Agents Chemother, 47 (2), 559-562.

9. Karah N, Poirel L, Bengtsson S, Sundqvist M, Kahlmeter G, Nordmann P, Sundsfjord A, Samuelsen O, Norwegian Study Group on PMQR (2010): Plasmidmediated quinolone resistance determinants $q n r$ and aac(6')-Ib-cr in Escherichia coli and Klebsiella spp. from Norway and Sweden. Diagn Microbiol Infect Dis, 66, 425431.

10. Kuo HC, Chou CC, Tu C, Gong SR, Han CL, Liao JW, Chang SK (2009): Characterization of plasmid-mediated quinolone resistance by the qnrS gene in Escherichia coli isolated from healthy chickens and pigs. Vet Med-Czech, 54 (10), 473-482.

11. Mammeri H, Van De Loo M, Poirel L MartinezMartinez L, Nordmann P (2005): Emergence of plasmidmediated quinolone resistance in Escherichia coli in Europe. Antimicrob Agents Chemother, 49, 71-76.

12. Martinez-Martinez L, Pascual A, Jacoby GA (1998): Quinolone resistance from a transferable plasmid. Lancet, 351, 797-799.

13. Nazik H, İlktaç M, Öngen B (2009): Prevalence of qnrA, $q n r B$, qnrS and aac(6')-lb-cr (in qnr-positive isolates) among the ESBL-positive and/or ciprofloxacin-resistant isolates in Turkey. J Chemother, 21 (2), 219-221.
14. Öktem İMA, Gülay $\mathrm{Z}$, Biçmen M, Gür D, HITIT Project Group (2008): qnrA prevalence in extendedspectrum $\beta$-lactamase-positive Enterobacteriaceae isolates from Turkey. Jpn J Infect Dis, 61, 13-17.

15. Poirel L, Rodriguez-Martinez JM, Mammeri H, Liard A, Nordmann P (2005): Origin of plasmid-mediated quinolone resistance determinant QnrA. Antimicrob Agents Chemother, 49, 3523-3525.

16. Rodriguez-Martinez JM, Cano ME, Velasco C, Martinez-Martinez L, Pascual A (2011): Plasmidmediated quinolone resistance: an update. J Infect Chemother, 17, 149-182.

17. Sambrook http://www.sciencedirect.com/science/article/pii/ S0956713506001964 - bbib14J, Russel DW (2001): Molecular cloning: A laboratory manual, (3rd ed). Cold Spring Harbor Press, Cold Spring Harbor, NY, USA.

18. Savaşan S, Çiftçi A, Diker KS (2004): Emergence of quinolone resistance among chicken isolates of campylobacter in Turkey. Turk J Vet Anim Sci, 28, 391397.

19. Tran JH, Jacoby GA (2002): Mechanism of plasmidmediated quinolone resistance. Proc Natl Acad Sci USA, 99, 5638-5642.

20. Wang M, Tran JH, Jacoby GA, Zhang Y, Wang F, Hooper DC (2003): Plasmid-mediated quinolone resistance in clinical isolates of Escherichia coli from Shanghai, China. Antimicrob Agents Chemother, 47, 2242-2248.

21. Wang M, Sahm DF, Jacoby GA, Hooper DC (2004): Emerging plasmid-mediated quinolone resistance associated with the qnr gene in Klebsiella pneumoniae clinical isolates in the United States. Antimicrob Agents Chemother, 48, 1295-1299.

22. Webber M, Piddock LJ (2001): Quinolone resistance in Escherichia coli. Vet Res, 32, 275-284.

23. Yue L, Jiang HX, Liao XP, Liu JH, Li SJ, Chen XY, Chen CX, Lu DH, Liu YH (2008): Prevalence of plasmid-mediated quinolone resistance qnr genes in poultry and swine clinical isolates of Escherichia coli. Vet Microbiol, 132, 414-420.

Geliş tarihi: 15.03.2012 / Kabul tarihi: 29.03.2012

Address for correspondence:

Dr. H. Kaan Müştak

Ankara University, Faculty of Veterinary Medicine,

Department of Microbiology

06110, Diskapi, Ankara, Turkey.

E-mail:kmustak@ankara.edu.tr 